кандидат філологічних наук, доцент кафедри української літератури та методики навчання Миколаївського національного університету імені В. О. Сухомлинського

\title{
«КРИЛА КОЛЬОРУ ХМАР» ДАРИ КОРНІЙ І ТАЛИ ВЛАДМИРОВОЇ: ПРОБЛЕМИ ТРАДИЦІЇ Й НОВАТОРСТВА В РОМАНІ
}

\begin{abstract}
Доведено превалювання в романі Дари Корній $і$ Тали Владмирової «Крила кольору хмар» ознак традиційної парадигми. Акцентовано системну спорідненість твору 3 зарубіжними аналогами міського фентезі на образному, мотивно-сюжетному $i$ міфопоетичному рівнях. Підтверджено загальні тенденції розвитку української фентезійної прози і перегук між романами Дари Корній.
\end{abstract}

Ключові слова: традиція, новаторство, фентезі, сюжет, типологія, подібність, інтертекстуальність, системність.

Доказано превалирование в романе Дары Корний и Таль Владмировой «Крылья ивета облаков» признаков традииионной парадигмы. Акиентировано системное родство произведения с зарубежными аналогами городского фэнтези на образном, мотивносюжетном и мифопоэтическом уровнях. Подтверждены общие тенденции развития украинской фэнтезийной прозы и перекличка романов Дары Корний.

Ключевье слова: традиция, новаторство, фэнтези, сюжет, типология, подобие, интертекстуальность, системность.

In this article the prevailing of the traditional paradigm signs in the novel "The Wings of Colour of Clouds» by Dara Korniy and Tala Vladmyrova is proved. The system kinship of the novel with the foreign analogues of the city fantasy on the image, the motif-plot and the mythopoetic levels is accented. The general tendencies of development of the Ukrainian fantasy prose and Dara Korniy's novels roll-call are confirmed.

Keywords: tradition, innovation, fantasy, plot, typology, intertextuality, resemblance, system organization.

Надії на віднайдення необхідної актуальної української міфології в літературі фентезі виправдані, та сильні настільки, що часом черговий твір відомого митця критиками без належного дослідження «призначається» національним досягненням. Подібну реакцію викликають романи Дари Корній, які, будучи суперечливим явищем у літературному процесі України, презентують активний пошук вітчизняним автором власного шляху. Необгрунтована ж оцінка [наприклад, див.: Корній 2015:5-6] призводить до утворення певного стереотипу в читача і письменника-початківця, а отже, - до деформації в їх очах і досягнень, і завдань української літератури початку XXI ст. У пропонованій статті, виконаній у руслі пріоритетної для 
вітчизняного літературознавства тематики, вперше намагаємось проаналізувати 3 позицій традиції й новаторства роман Дари Корній i Тали Владмирової «Крила кольору хмар», при цьому основну увагу звертаючи на а) різнорівневі сходження твору 3 зарубіжними зразками жанру, б) нові акценти в інтерпретації легендарно-міфологічного матеріалу i в) специфічні маркери авторства Дари Корній у романі.

Дара Корній (Мирослава Замойська) увійшла до числа українських романістів відносно нещодавно як продуктивний і комерційно успішний автор. Після нашумілого «Гонихмарника» 2010 р. (III премія Всеукраїнського конкурсу романів, кіносценаріїв та п’єс «Коронація слова - 2010», премія Міжнародної асамблеї фантастики «Портал - 2011») світ побачили «Тому, що ти є» 2010-2011 р., «Зірка для тебе» 2012 р.; «Зворотний бік світла» 2012 р. і «Зворотний бік темряви» 2013 р. (дві частини циклу, «Зворотний бік сутіні» ще не виданий); «Щоденник Мавки» 2013-2014 pp., а також «Зозулята зими» і «Крила кольору хмар» 2014 р. (далі в тексті статті - «Крила...»). Останні дві книги написані у співавторстві з Талою Владмировою (Таміла Тарасенко) автором переважно оповідань. Системний аналіз і тенденції розвитку міфопоетики прози Дари Корній вперше запропоновано А. Гурдузом [зокрема, див.: Гурдуз 2012; Гурдуз 2014; Гурдуз 2014 Міфопоетика]; особливості іiі стилю розглядають Л. Романенко, Т. Белімова; швидше емоційними є більшість схвальних відгуків і рецензій - К. Соснюк і Ю. Железної, Н. Ліщинської, Тали Владмирової й ін., а також передмови до виданих творів (зокрема, Люко Дашвар, Г. Пагутяк, О. Хвостової, Т. Белімової). Оповідання ж Тали Владмирової поки розглядаються в інтернет-відгуках [Владмирова 2015].

Текст «Крил...» підтверджує означену нами тенденцію переходу в книжках Дари Корній (iї роль в авторському тандемі провідна) до східноєвропейських (у першу чергу, слов'янських) мистецьких орієнтирів [Гурдуз 2014:66] (вельми відчутний елемент запозичення ускладнює мистецьку оцінку ऑï прози). Російський романний цикл про Варти С. Лук’яненка 1998-2014 рр. відіграє роль структурної (сюжетної) опори для 
«Крил...» так само, як і для «Зворотного боку світла» i «Зворотного боку темряви». Подібно до художнього світу «Варт», протистояння представників добра i зла (світлих і темних ангелів) в українському творі ускладнене існуванням третьої сторони, яка своєрідно врівноважує опозиційні сили, сірих ангелів, причому протистояння основних опонентів швидше заявлене, оскільки фокус переноситься на специфіку взаємин сірих ангелів і людей (нагадаємо, що ускладнення опозиції «добро - зло» до тріади є тенденцією в мистецтві кінця ХХ ст. [Гурдуз 2009 Постійність:63]). Прикметне наголошення в творах згубності для людського світу перемоги однієї зі сторін вічного конфлікту, представники яких традиційно для міського фентезі ведуть подвійне життя. Знову-таки, містична варта міста Львова презентована як таємна структурована організація переважно Інших (але на чолі з Хранителемлюдиною). Повторюване ж у романі положення про невизначальність кольору крил для сутності ангела [Корній 2015:273; Корній 2015:310] відповідає аналогічному моменту з ініціалізацією Іншого в російських «Вартах», відтак в українському творі можна розпізнати сюжетну варіацію на першу книгу циклу С. Лук’яненка «Нічна Варта» (скажімо, боротьба за вибір «виявленого» сірого ангела Аделаїди співвідносна 3 боротьбою добра і зла за ініціалізацію хлопчика-Іншого Єгора). Крім того, спосіб сприймання героїнею Аделаїдою чужих душ (наприклад, у колекції демонічного Валерія Едуардовича) «візуалізація» [Корній 2015:99] - відповідає типу проявлення сутності Інших у Сутінку «Варт».

Згадується, як i під час аналізу «Зворотного боку світла» [Гурдуз 2014:67], й перша книга циклу М. і С. Дяченків «Блукачі»: спорідненість підведення i розгортання пов'язаної із входом до таємного порталу художньої ситуації в «Брамнику» 1994 р. і «Крилах...» очевидна (закономірно, що й дізнаються герої цих творів, Руал і Аделаїда, про свою місію - відповідно Брамника і Воротаря - раптово для них самих). Назва нічного клубу, де певний час працює Аделаїда, - «Темний янгол»- змушує пригадати таверну «Розпусний єдиноріг» в «Історіях таверни «Розпусний 
єдиноріг»») Р. Асприна і Л. Еббі 1980 р., особливо коли взяти до уваги описи вивісок клубу i таверни (парадоксалізм власних назв у творах, де переосмислюються легендарно-міфологічні образи, відомий: пригадаймо хоча б трактир «Ручний єдиноріг» у романі А. Астахова «Машина Апокаліпсису» 2008 р. $з$ циклу „RPG”). Оксюморонні назви розважальних закладів у вказаних творах синонімічні так само, як співвідносно переосмислені в тенденції мистецтва II половини XX-XXI ст. образи відповідно ангела i єдинорога (прийняті в християнстві за втілення абсолютного добра, вони в цей період інтерпретуються до діаметрально протилежних значень [детальніше див.: Гурдуз 2010:109]). Ідея ж змальованої в українському творі колекції «ув’язнених» душ надприродних істот Валерія Едуардовича перегукується 3 описом чарівних книг із зображенням єдинорогів у «Чорному єдинорозі» Т. Брукса 1987 р., що малюнки тварин на сторінках цих книг символізували полонені і в результаті - також звільнені душі диво-коней.

Твердження в аналізованому романі про наявність душ як в ангелів, так і у вампірів органічне тій же тенденції реінтерпретації легендарноміфологічного образу в літературі II половини XX-XXI ст. - корпусу, де вампіри релігійні, а люди створені ними чи хочуть бути ними [Гурдуз 2013:68-71]; де одухотворений Мінотавр з'єднує характеристики образів Робінзона й Агасфера чи Христа, Прометея і под.; де існують цивілізації мінотаврів [Гурдуз 2009:55] i єдинорогів, a останні можуть бути антропоморфізованими і т. ін. [Гурдуз 2010:108-109]; де душа визнається навіть у Франкенштейна чи гарпій - захисників добра (фільм «Я, Франкенштейн» реж. С. Бітті, 2014 р., США - Австралія) і под.

Застосований у «Крилах...» прийом 3 утіленням ангельської істоти в людському тілі, коли ангел закохується в жінку, також відомий і презентований, скажімо, в драмі «Небо над Берліном» 1987 р. (ФРН, Франція), ii продовженні «Так далеко, так близько!» 1993 р. реж. В. Вендерса (Німеччина) чи римейку «Місто ангелів» реж. Б. Силберлінга 1998 р. (США, Німеччина). Ігровий принцип уведення до тексту «Крил...» інформації про 
«сірuх» ангелів («з легенди») - традиційний для вирішення подібних завдань художній хід: сутність об'єкта реінтерпретації виявляється в діалозі персонажів (у першу чергу, Аделаїди й «ловця душ» Валерія Едуардовича і Мечислава). Наявність своєрідних «довідок» про відповідні легендарноміфологічні образи чи об'єкти в художніх творах мотивована модою і необхідністю інформувати не завжди культурно підготовленого до розуміння твору читача (аналогічно див.: «Останній єдиноріг» П. Бігла 1968 р., «Звільнений Франкенштейн» Б. Олдисса 1973 р., «Сдинороговий гамбіт» Д. Бішофа 1986 р., «Код Атлантиди» С. Павлоу 2001 р., «Голем, російська версія» А. Левкина 2002 р., «Атлантида» Д. Гіббінса 2006 р., «Дзеркало єдинорога» Л. Таран 2008 р., «Тимур та його команда і вампіри» Т. Корольової 2012 р. тощо). Такі фрагменти можуть бути оформлені як діалоги персонажів (наприклад, у П. Бігла, Д. Бішофа, С. Павлоу, Т. Корольової) чи безпосередньо вставлені в текст (у романі Л. Таран). Загальним місцем при цьому [Нямцу 2007:39] є й зауваження в тексті «Крил...» про те, що традиційні культурно-релігійні відомості про «сірих» ангелів $є$ невірними і саме в прочитуваному творі подана істинна інформація [Корній 2015:82] (аналогічні «заяви» про вампірів знаходимо, наприклад, у «Вартах» С. Лук’яненка, «Бетмані Аполло» В. Пелевіна, «Блакитній крові» М. де ла Круз і под.).

Окремо слід сказати про маркери авторства Дари Корній у тексті «Крил...» (книга написана у співавторстві), реалізовані через підкреслення зв’язку аналізованого роману з їі попередніми творами (про подібні перегуки в прозі мисткині ми вже говорили [Гурдуз 2014:67]). Так, героїня Аделаїда «колись запитувала себе: щуо таке темрява? Невже лише відсутність світла?» [Корній 2015:20]. I в ранішому «Гонихмарнику» знаходимо: «...чорне - це лищень відсутність потоку світла...» [Корній 2010:14]. Тобто в романі 2014 р. трансформована прогресивна самоцитація: адже фраза має продовження: «A якщзо в душі? Biдсутність любові?» [Корній 2015:20]. У такий спосіб, наведений фрагмент «Крил...» можна трактувати як підкреслення й авторства в тексті, і того факту, що героїня твору - одна 3 
іпостасей «крилатої» метагероїні романістики Дари Корній (тоді багатозначним стає сполучення прислівника «колись» і минулого часу дієслова «запитувала»).

Очевидна співвідносність композиційної концепції «Крил...» і «Зірки для тебе» (інсталяції притч, легенд і под.), активне залучення до тексту цих романів поезій Любові Долик; симптоматичним бачиться коментар у «Крилах...» щодо постатей козака Мамая $\mathrm{i}$ характерника як такого [Корній 2015:256] - одної з провідних тем «Щоденника Мавки». У роздумах же Аделаїди про необхідного ій помічника вона оцінює друга: «Віктор... людина, не супермен. ...точно не святий Юрій Змієборещь» [Корній 2015:211]. Згадка про святого, очевидно, мотивована не тільки тим, що він $є$ патроном Львова, де відбуваються події роману, - саме святий Юрій безпосередньо допомагає головним героям «Гонихмарника» перемогти зло. Крім того, у «Крилах...» спостерігаємо «знайомий» для прози Дари Корній мотив виховання в звичайних умовах дівчинки 3 надприродними здібностями iз пізнішим «просвітництвом» підлітка - як, наприклад, у «Зворотному боці світла». Подібна ситуація 3 наступним вибором героя своєї сторони «сили» практикована в фентезійному мистецтві: цим i ще рядом типологічно споріднених художніх рішень сюжет «Крил...» відповідає сюжету американського кіноциклу за книгами Т. Снігорські «Грішний» 2006 . (реж. М. Саломон і К. Керслейк), іспанського телесеріалу «Ангел чи демон» 2011 p. (реж. Е. Кортес, Г. Лопес-Гальєго і М. Бардем) і його російської однойменної адаптації 2013 p. (реж. М. Горобець і С. Іванов). Інтертекстуальний шар «Крил...» [Корній 2015:145-146], як і аналіз романів інших вітчизняних письменниць межі XX-XXI ст. (наприклад, Л. Баграт, В. Гранецької), свідчить про важливість для цих мисткинь творів кіноіндустрії.

Очевидно, більше шансів у плані оригінальності художніх ходів авторки «Крил...» мали в розкритті власне українського колориту місця і часу подій, хоча вплив жанрового досвіду позначився i тут. Типологічно подібно до презентації містичного життя Львова з відповідними географічними акцентами 
змальовано «втаємничений» Париж у вищезгаданій картині С. Бітті «Я, Франкенштейн» (прем’єрний показ відбувся в січні 2014 р., а рукопис аналізованого роману підписано до друку в березні 2015 р. [Корній 2015:316]), хоча прикладом художньої ситуації можуть слугувати і твори з зображенням паралельних і водночас реальних світів - телесеріал «Межа» Дж. Дж. Абрамса, А. Куртцмана i P. Opci 2008-2013 pp. (США) i под. Продуктивного ж поглиблення роботи 3 матеріалом національної міфології (на що орієнтували попередні романи Дари Корній і власне зацікавлення обох письменниць) у «Крилах...» не спостерігаємо. Отже, «сакралізаиія і десакралізащія звичайного $\check{u}$ усталеного» не забезпечили розширення аналізованим романом «фантастичного виміру у сучасній украӥнській прозі» [Корній 2015:5], оскільки вписалися в широку вказану вище мистецьку тенденцію. Новим у «Крилах...», швидше, є посилення окремих акцентів деміфологізації (причому дещо ризиковане: наприклад, положення про відсутність в ангелів моралі [Корній 2015:166] - хоча і в цьому плані можна пригадати роман Г. Зотова «Пекло \& Рай» 2011 р.), ситуативна міфопоетична комбінаторика, за допомогою якої авторкам удається сформувати відносно цілісну фентезійну картину.

Пам'ятаючи про необов'язковість виконання літературою моральнодидактичної функції, зауважимо, однак, що у взаєминах персонажів «Крил...» окремі казуси викликають занепокоєння (до того ж, основна читацька аудиторія фентезі - юнацька). Дізнаючись про злочини батька, юний ангел Аделаїда не тільки зневажливо говорить із ним, вживаючи й лайливу лексику [Корній 2015:250], - героїня 3 легкістю, без душевних мук іде на батьковбивство. Не виправдовуючи потворних учинків Мечислава, підкреслимо, що в українській чи й загальнокультурній традиції зневажливе ставлення до батьків безвідносно до їх моральної поведінки відсутнє, тим більше їх убивство. Названий крок героїні суперечить тому, що Аделаїда як ангел робить вибір на користь добра, а також факту іiі виключно тонкої душевної організації, яка дозволяє дівчині «підзаряджатися» від енергії сонця 
тощо. Тобто невиправдана жорстокість душі героїні суперечить і моральній системі, і мотивній логіці роману (хоча, знову ж таки, в тексті проходить думка про відсутність в ангелів моралі). Для адекватного зіставлення пригадаймо, що в типологічно спорідненому 3 «Крилами...» «Грішному» М. Саломона і К. Керслейка підліток - спокутувач ангелів Аарон Корбет у поєдинку з батьком (той виявляється Люцифером) не вбиває/знищує його, а скидає в пекло. Переживає муки, наказуючи стратити доньку за зраду, старійшина клану вампірів Віктор у частині пенталогії «Інший світ: Повстання ліканів» реж. П. Татопулоса 2009 р. (США), а, скажімо, в «Нації вампірів» реж. Т. Чапканова 2012 р. (США) ватажок нежиті просить не вбивати його сина, хоча той після мутації знищує самих вампірів.

Нарешті, відчутні в тексті «Крил...» певні мовно-стилістичні недоліки (чим «грішить» проза Дари Корній [Гурдуз 2012:234-235]): невиправдане застосування лайливої чи згрубілої лексики в мовленні героїні - сірого ангела на шляху добра, Хранителя Львова Олега [Корній 2015:276] й ін. Здивування викликають окремі опуси: наприклад, слова маленької дівчинки Христі про закоханого в Аделаїду Віктора: «Дузе-дузе холосий Вітюса. Але він не дузе людина, Адо, він - цэоловік» - і їх коментар героїнею: «Я такого й від дорослих знайомих феміністок не чула. ... «Чоловік - не зовсім людина! Тому його ображати не треба». Усміхаюся мимоволі» [Корній 2015:240].

Як видно, роман «Крила кольору хмар» засвідчує не тільки певне творче зростання його авторок (для Тали Владмирової це другий крок у «великій» прозі, а Дара Корній загалом, за власним зізнанням, продовжує «вчитися» [Корній 2013:13]): він підтверджує тяжіння українських фентезійних письменниць до міфопоетичної комбінаторики 3 опорою все ще переважно на зарубіжний мистецький досвід 3 аспектним залученням національного культурно-літературного матеріалу, хоча бажаним є більш продуктивний шлях [Гурдуз 2014:68] (тим не менше, на церемонії нагородження Міжнародного літературного конкурсу «Коронація слова - 2015» уже були вручені спеціальні відзнаки від Дари Корній і Тали Владмирової «Українське сучасне фентезі»). 
Упевнені, що оперативна об’єктивна оцінка нових вітчизняних творів повинна даватися 3 позицій компаративності і системності, сприяючи тим самим корекції літературно-мистецького процесу i формуванню адекватного смаку реципієнта. Віднайдення «власного унікального... шляху» [Корній 2015:5] в жанрі фентезі Дарою Корній і Талою Владмировою ще попереду, але еволюція їх творчості в силу художнього потенціалу заслуговує на подальше дослідження в контексті розвитку українського письменства початку XXI століття.

\section{БІБЛІОГРАФІЯ}

Владмирова 2015 - Владмирова Т. Твори [Електронний ресурс] / Тала Владмирова // Гоголівська академія. - Режим доступу : gak.com.ua/authors/1791.

Гурдуз 2010 - Гурдуз А. І. Амплітуда переосмислення образу єдинорога в літературі XX - першого десятиліття XXI ст. // Новітня філологія. - Миколаїв : Вид-во Чорномор. держ. ун-ту ім. П. Могили, 2010. - № 37. - С. 99-115.

Гурдуз 2009 - Гурдуз А. I. Літературна мінотавріана XX - початку XXI ст. / А. І. Гурдуз // Зарубіжна література в школах України. - 2009. - № 6. C. 51-56.

Гурдуз 2013 - Гурдуз А. I. Літературно-мистецька вампіріада другої половини XX - першого десятиліття XXI століть: інтрига переосмислення / А. I. Гурдуз // Науковий вісник : зб. наук. пр. / Миколаїв. держ. ун-т iм. В. О. Сухомлинського. Сер. : Філологічні науки. - Миколаїв : МНУ ім. В. О. Сухомлинського, 2013. - Вип. 4.12 (96). - С. 64-72.

Гурдуз 2014 - Гурдуз А. I. Міжкультурний діалог як проблема українського фентезі XXI століття / А. І. Гурдуз // Науковий вісник : зб. наук. пр. / Миколаїв. держ. ун-т ім. В. О. Сухомлинського. Сер. : Філологічні науки. - Миколаїв : МНУ ім. В. О. Сухомлинського, 2014. - Вип. 4.14. C. 63-69.

Гурдуз 2014 Міфопоетика - Гурдуз А. I. Міфопоетика «жіночого» містичного любовного роману першого десятиліття XXI ст. в Україні/ А. I. Гурдуз // Науковий вісник : зб. наук. пр. / Миколаїв. держ. ун-т Літератури світу: поетика, ментальність і духовність. - 2015. - Вип.6. 
ім. В. О. Сухомлинського. Сер. : Філологічні науки (літературознавство). Миколаїв : МНУ ім. В. О. Сухомлинського, 2014. - Вип. 4.13 (104). - С. 61-68.

Гурдуз 2009 Постійність - Гурдуз А. І. Постійність рухливого: ізоморфізм ключових традиційних образів і мотивів у літературі / А. І. Гурдуз // Зарубіжна література в школах країни. - 2009. - № 12. - С. 63-64.

Гурдуз 2012 - Гурдуз А. Роман Дари Корній «Гонихмарник»: місце в мистецькому контексті 3 погляду традиції й новаторства / А. Гурдуз // Українознавчий альманах. - К. ; Мелітополь. - 2012. - Вип. 9. - С. 229-235.

Корній 2010 - Корній Д. Гонихмарник / Дара Корній ; передм. Люко Дашвар. - Харків : Книжковий клуб «Клуб сімейного дозвілля», 2010. - 336 с.

Корній 2015 - Корній Д. Крила кольору хмар : роман / Дара Корній, Тала Владмирова ; передм. Т. Белімової. - Харків : Книжковий клуб «Клуб сімейного дозвілля», 2015. - 320 с.

Корній 2013 - Корній Д. «Треба розбудити нашу генетичну пам’ять» : інтерв’ю [Електронний ресурс]/ Дара Корній ; вела I. Ковалишена // Світ Фентезі : електронний літературний щомісячник. - 2013. - № 3 (3). - С. 12-15. Режим доступу : issuu.com/580709/docs/_3_1.

Нямцу 2007 - Нямцу А. Миф. Легенда. Литература : (теоретические аспекты функционирования) : моногр. / А. Нямцу. - Черновцы : Рута, 2007. $520 \mathrm{c}$. 